\title{
ANALYSIS OF FACTORS FOR ENHANCING ENERGY CONSERVATION IN INDIAN RAILWAY WORKSHOPS: A CASE STUDY
}

\author{
Suresh D. Mane ${ }^{1}$, N. Nagesha ${ }^{2}$ \\ ${ }^{1}$ Research Scholar, Dept. of Industrial and Production Engineering, UBDT College of Engineering, Davangere, \\ Karnataka India 577004 \\ ${ }^{2}$ Professor, Dept. of Industrial and Production Engineering, UBDT College of Engineering, Davangere, Karnataka, India \\ 577004
}

\begin{abstract}
Indian Railways (IR) has 41 workshops spread over the entire nation which are into maintenance of its fleet of rolling stock viz. the locomotives, coaches and wagons, and also undertake the manufacturing of components required for maintenance. These workshops are grand old establishments set up mainly during the British raj for maintenance of bygone era steam locomotives, wooden bodied coaches and rivetted body wagons. These workshops employ thousands of technical manpower and are also energy intensive in nature mainly consuming electricity, diesel and LPG. An empirical study was undertaken covering two railway workshops viz., Carriage Repair workshop, Hubli (UBLS) and Central Workshops, Mysore (MYSS) to understand the different variables which affect the usage and conservation of energy. The respondents were officers and engineers (Senior Section Engineers) of these two workshops who are technically qualified and have rich experience. The cumulative experience of 71 respondents of UBLS was 1491 years which means the average experience per respondent was 21 years. From the face to face interviews with the respondents in both the workshops 25 variables were included for data collection. Questionnaire was designed covering all the 25 variables and administered to respondents in both the workshops separately and their preferences were recorded on a five point Lickerts scale. Totally, 128 respondents out of the population of 375 i.e. one third of the population filled up the questionnaire with 71 being from UBLS and 57 from MYSS. Principal Component Analysis (PCA) method of extraction of factors for the combined data resulted in emergence of 8 factors. They include 'Motivation to employees', 'Knowledge and attitude', 'Preventive measures', Timely decision making', 'Motivation for energy conservation', 'Management role', 'Procurement process', and 'Human factor'. The outcome of the study has greater policy implications as sustainable development demands new strategies, solutions and policy making approaches
\end{abstract}

Keywords: Indian Railways, Carriage Repair Workshops, Energy Conservation, Factor Analysis, Principal Component Analysis

\section{INTRODUCTION}

Energy is a scarce commodity in India, an energy deficit nation, as it suffers from stagnation in domestic oil production and continued increase in oil imports over the years [1]. Hence, Demand Side Management (DSM) and judicious use are vital for matching the demand and supply of energy. India is perennially an energy importing nation and is shelling out nearly 7934 million USD annually in foreign exchange to import the crude oil. Central Electricity Authority vide its Load Generation Balance Report of 2013 pegs India's annual requirement of electricity at 10,48,533 Million Units (MU). However, the supply is $9,78,301 \mathrm{MU}$ leading to a shortfall of 70,237 MU i.e. a deficit of $6.7 \%$ [2]. DSM of power can assuage the situation to some extent without incurring major costs as involved in augmenting the energy generation capacity. The demand for energy comes from various sectors of economy like Agriculture, Residential, Commercial, Industrial, and Transport. Indian Railways (IR) is among the world's largest transporter of men and material employing over 1.4 million workforce in its 17 zones [3]. IR is one of the major energy consumer in the transport sector in terms of electricity and diesel and accounts for about $2.5 \%$ of national electricity use.

\subsection{Indian Railways Current Energy Scenario}

During the year 2012-13, IR spent 154 million USD towards electricity charges and consumed 17.15 billion units of electricity and 2.35 billion litres of diesel [4]. The railway budget of IR for the year 2013-14 makes a total allocation of 421 million USD for fuel, with 267 million USD and 154 million USD towards diesel traction and electricity charges respectively [5]. Such significant allocation has prompted IR to establish a Railway Energy Management Company (REMC) to bring efficiency in energy use and help in power purchases. Further, with the intention of reducing the nation's growing dependence on petroleum imports, IR has implemented several Energy Conservation Measures (ECM) and is also a frontrunner in adopting Energy Efficient 
Technologies (EETs) and Renewable Energy Technologies (RETs). This is demonstrated from the fact that the IR received 11 National Energy Conservation Awards, the highest ever by any Indian industry, from Bureau of Energy Efficiency (BEE) Ministry of Power Government of India, for the remarkable achievements in Energy Conservation (EC) initiatives taken during 2012 and further improved its tally to 22 awards for the year 2013 [6].Most of the ECMs are advised by the Railway Board (RB) to Zonal Railways and the Production units for time bound implementation.

Workshops in IR were established long ago during British Raj and they have constantly upgraded their infrastructure to cope up with the growing demands of the passenger traffic. Energy in the form of electricity and diesel is mainly consumed for traction purpose and also for the non-traction applications with 41 workshops of IR having a giant share in it. IR has a fleet of 53220 coaches with 6493 other passenger vehicles, which are regularly maintained at these 41 workshops spread over 17 zones. These coaching vehicles need sustained attention, in order to keep them in good state of repair, fit to perform their functions safely and efficiently. Periodical overhauls - POHs for short are carried out in workshops at intervals, on a time or a mileage basis. Hence IR has a periodical overhauling (POH) policy wherein all the passenger carrying coaches are brought to workshops after serving for 18 months, so that they are thoroughly attended. During the $\mathrm{POH}$, coaches are completely stripped, every component is thoroughly examined, repairs and replacements carried out and the unit rebuilt and made as good as new. In between successive $\mathrm{POH}$, intermediate overhaul ( $\mathrm{IOH})$ is also undertaken at an interval of 9 months wherein the bogies, the components viz., running gear, draft gear, suspension gear, brake gear are all dismantled and thoroughly overhauled. Energy usage in workshops is maintained by the respective Divisional Electrical Officer with a team of supervisors. The RB fixes the targets for $\mathrm{POH}$ of the workshops and also the power consumption target annually and monitors them closely [7]. RB has also set up 28 point action plan for $\mathrm{EC}$ and implementation of renewable energy in its operations.

\subsection{Carriage Repair Workshops at Hubli and Mysore}

Paragraph Carriage Repair Workshop, Hubli (UBLS) and Central Workshops, Mysore (MYSS) are two major workshops employing 3300 and 1800 strong workforce respectively[8 \& 9]. They are in the core business of maintenance of coaches and are also involved in manufacturing important components for internal usage viz., bogies, brake vans and brake blocks. Both these workshops are the forerunners in successfully implementing and maintaining various ECM and RETs over the years and thus have been selected for the current study to analyze the barriers for EC efforts. A pilot study was conducted to arrive at different variables which are potentially influencing EC efforts directly or indirectly.

\section{LITERATURE REVIEW}

In the recent years, many a researchers around the world are undertaking study to determine ways and means to reduce the consumption of conventional energy and thereby mitigate its consequential environmental impact. The studies are undertaken in all sectors of economy like Residential sector, Commercial sector, Industrial sector, Transportation, and Agricultural sector. Through an empirical study, Somashekar and Nagesha (2010) have arrived at ten vital factors influencing domestic household energy consumption using Factor Analysis (FA) and Principal Component Analysis (PCA) method of factor extraction [10]. Earlier Nagesha and Balachandra (2006) had studied the Barriers to Energy Efficiency in SSI Clusters; by using the Multicriteria based prioritisation method duly using Aalytical Hierarchy Process [11]. Andreas et al (2012) have carried out the well to wheel analysis for electric, diesel and hydrogen traction for railways and concluded that a reduction of $19 \%$ in $\mathrm{CO} 2$ emissions can be achieved when hydrogen gas is used in a fuel cell compared to diesel traction [12]. They found that hydrogen gas used in fuel cell will result in 3\% lower $\mathrm{CO} 2$ emissions compared to US electricity. Ross Morrow et al (2010) studied the US transportation sector and found that the transportation sector alone consumes the majority of US's imported oil and produces a third of US green house gas (GHG) emissions. They used the Energy Information Administration's National Energy Modelling System and found that the policy scenario failed to meet the goal of reducing GHG emissions $14 \%$ below 2005 levels by 2020 [13]. They concluded that largest reductions in GHG emissions result from increasing cost of driving, thereby damping growth in vehicle miles travelled. Abdelaziz et al (2011) reviewed the energy saving technologies in the industrial sector which is consuming $27 \%$ of the world's total delivered energy [14]. They concluded that by using energy saving technologies such as high efficiency motors, variable speed drives, economisers, leak prevention and reducing pressure drop in the industrial sector a sizable amount of electric energy emissions and utility bill can be saved by these technologies.

Jenny Palm and Patrik Thollander (2010) combined engineering and social sciences approach to enhance understanding of industrial energy efficiency and broadened perspective on policy making in Europe [15]. They found that cost effective energy efficient technologies were not implemented for various reasons such as lack of information, procedural impediments and routines not favouring energy efficiency. According to Weber (1997), energy consumption belongs to the realm of technology but energy conservation to the realm of society. Since efficiency improvement is a part of energy conservation strategy, a whole lot of social factors are relevant, in addition to energy technology [16]. Baranzi and Giovannini (1996) link energy consumption to four major factors viz. technological, economic and financial, institutional, and cultural [17]. They observe, technical factors 
based on energy using equipment and economic \& financial factors in terms of income \& relative energy prices have attracted much attention in the past and stressed for increased attention to institutional and cultural factors in the future. Shunping et al (2009) have summarized the research achievements on transportation energy use such as external cost determination of energy consumption, analysis of influencing factors, and put forward key issues concerning future research [18]. Dasgupta (1999), after analyzing some initiatives of energy efficiency and environmental improvements in Indian small scale industries, is of the opinion that a technocratic top-down approach for energy efficiency improvement is not comprehensive. Advocating a bottom-up participatory approach, she emphasizes the need to address other non-technical factors associated with energy efficiency such as resource use efficiency, waste management, poor work practices, layout and house-keeping, etc. Thus, it may be observed that many researchers around the world agree that non-technology factors are as important as technological factors in improving energy efficiency and enhancing energy conservation. In this backdrop, the current study primarily aims to probe the various technical and nontechnical factors which are likely to influence the adoption of EC measures and energy efficient technologies in the selected two railway workshops.

\subsection{An Overview of Workshops under Study}

Present study focuses on two major carriage repair workshops located in south Indian cities of Hubli and Mysore in the state of Karnataka. The Carriage Repair Workshop-Hubli (UBLS) has been established in 1885 and Central Workshop-Mysore (MYSS) has been established in 1924 both of which primarily focus on broad gauge coach $\mathrm{POH}$ activity [19]. UBLS has diversified into manufacturing of steel bogies, guard brake vans, and MYSS into fabrication of toy trains and manufacturing of composite brake blocks. UBLS having 3400 staff caters to outturn of 654 Non-AC Coach POH, 91 ACCoach POH, IOH of 689 bogies, and Refurbishment of 115 coaches. Further, manufacturing 3005 bogies, 177 brake vans and 1625 bolsters, was under taken in 2011, which totals to 3020 equated coach units. MYSS has undertaken POH of 591 Non-AC Coach, POH of 120 AC-Coach, IOH of 550 bogies, and Refurbishment of 46 coaches apart from manufacturing one toy train and 63000 composite brake blocks which amounts to 1049 equated coach units for the year 2011. Contract Demand for UBLS is $1950 \mathrm{kVA}$ [20] and that of MYSS is $800 \mathrm{kVA}$ [21] and the connected loads are 9500 $\mathrm{kVA}$ and $5500 \mathrm{kVA}$ respectively. Both the workshops have in house captive Diesel Generating sets (DG) which are pressed into service during power cuts by distribution companies. Energy studies undertaken by IR are carried out separately by Mechanical and Electrical departments for fuels and electricity respectively. Detailed energy audits carried out by professional organizations at sister workshops viz.; Carriage Repair Workshop at Tirupati (South Central Railway) and
Carriage Works Perambur (Southern Railway) have also considered only electrical energy [22]. Thus, combined and comprehensive studies involving all forms of energy are not available in IR, to the best of author's knowledge. In this backdrop, an attempt has been made in this paper to encompass the various forms of energy consumed by coach repair workshops and study the factors influencing energy use and conservation.

\section{MATERIALS AND METHOD}

Workshops over IR primarily undertake preventive maintenance of rolling stock and are also involved in manufacturing of components for in-house usage. This paper attempts to probe the various factors which influence the adoption of ECM and EETs in the workshops of IR. Exploratory research was undertaken by conducting focused group discussions, unstructured interviews with knowledgeable and experienced people to arrive at the 25 variables which are as follows

1. Motivation to Employees - There is need for motivating the employees towards energy conservation. The drive to conserve energy and contribute in reduction of imports needs to be instilled by way of motivation which can be in monetary terms or in form of awards/recognition.

2. Ego/ Feeling of Insignificance - There is a general feeling amongst the staff that their role is insignificant and hence they do not appreciate their role in the EC drive.

3. Proper Machine /equipment Operation - The workshops activities are totally dependent on machinery and equipment. Proper operation of the machinery and equipment can contribute towards achieving EC

4. Attitude of Staff - The workshops are labour intensive units and hence the attitude of staff towards the EC measures plays a role in installing EET and sustaining the EC measures.

5. Periodical Training - Regular training to all the concerned staff about the EC activities shall sensitise them and they can play better roles towards enhancing EC in the workshops.

6. Increased Awareness - Awareness about EC can be brought about by various means viz. Posters, Leaflets, Brochures, role plays etc

7. Machinery Mishandling - Mishandling of the equipment unintentionally or deliberately lead can to increase in energy consumption such as in the case of fork lift trucks

8. Prompt Decision Making - Prompt decision making in approving the purchase, undertaking purchase of equipment or spares for equipment shall lead to better EC

9. Ill Effects of pollution - The ill effect of increased energy consumption will be pollution at local level as well as at global level at generation point and as such should be a deterrent for increased energy consumption.

10. Management role - The leader plays an important role in any organisation and IR is no exception to it. Proactive sustained measures by the management can bring visible and tangible change and lead the workshops to greater achievements in the field of EE, RET and EC. 
11. Technology of Machines - The use of energy efficient devices is a factor which need consideration as majority of the electrical energy is consumed by the machinery and equipment.

12. Overloading/Under loading of Machines - Optimum loading of the machinery and equipment ensures the longevity of the equipment and also ensures better EC

13. Periodical Maintenance of Machines - Maintenance of machinery, lubrication, resetting, and replacement of consumables at regular intervals with original equipment spares can contribute towards EC.

14. Long Procurement Process - The procurement process for stocked and non stocked items are different but in order to promote EC the processes can be simplified or centralised to ensure availability of EET

15. Simplified Procurement process - The procurement process per se is cumbersome and involves finance concurrence, various stages and at times acts as a deterrent for initiating procurement of EET equipment

16. Focus on Quantity of Output - There is more focus on the quantity of output as it is reviewed on a daily basis at workshop level and on monthly basis the zonal level and Railway Board level. This takes away the drive to improve or build in quality during maintenance.

17. Centralised Decision making - Railway Board and Zonal Railways are bestowed greater financial and policy making powers and many a times the workshops are unable to undertake new EC projects due to limited power as laid down in the Schedule of Powers.

18. Trade Unions role - Railways have a strong labour union organisation to prevent exploitation of the working class and to ensure better bargaining power and safer working environment. Trade unions influence the working class and at times oppose the introduction of new technologies for the fear of reduction in man power requirement

19. Transfer Policy - There is no fixed and sacrosanct transfer policy and it mainly depends on the person empowered to take decisions. This leads to premature transfers and in appropriate postings which reduces the drive of the executives, supervising engineers to undertake EC activities

20. Finance department - As procurement proposals above a certain monitory limit need to have finance concurrence, it can so happen that they face the axe as finance is focussed on returns on investment and many a times financially these EET are not that encouraging

21. Lowest Cost Procurement Policy - The well defined procurement policy as per the Indian Railways Stores Code is scrupulously followed by the executives and mostly the lowest tenderer is awarded the tender overlooking the better technology product offers. The focus is just on the initial cost rather than the life cycle cost and as such most of the time poor performing products are procured and utilised.

22. Awards for Motivation - To create a drive for EC amongst the associates, awards need to be constituted within the workshops to increase the spirit of EC amongst the constituent shops.
23. Monitoring health of Fork Lifts - It is observed that the internal material handling equipment are poorly maintained for want of quality spares which leads to increased fuel consumption to cite an example excessive idling for want of either good battery or the starter motor.

24. Regular Meetings regarding EC - To implement and sustain EC movement regular meetings need to be conducted which shall increase the awareness levels and drive the EC movement to achieve progress

25. Inventory Management of Spares - Many a times the machinery and equipment are kept idle for want of spares as the lead time to procure imported spares is too long and involves many bureaucratic hurdles. For want of the spares the EET machines are kept idle and local make equipment which are energy guzzlers are extensively utilised as their spares are locally available and they are more rugged.

IR Workshops have the following chain of command Officers - Engineers (Senior \& Junior) -Technicians in Grade I, II \& III) followed by Supporting Staff. Informal surveys and focussed group interviews were conducted initially with most of the officers and senior most engineers of both the workshops to arrive at the variables influencing EC. Initially, opinions pertaining to 25 variables were collected from the face to face interviews with respondents of both the workshops which were correlated and standardised. Subsequently, suitable questionnaire was devised to capture the responses of the stakeholders using five point Lickerts scale. The respondents in the study comprised the officers and senior section engineers of both the workshops. The 25 variables were arranged appropriately in a structured questionnaire and administered to 128 respondents out of the total 375 officers and supervising engineers thereby covering one third of the population. The respondents are qualified engineers with minimum qualification of diploma in engineering and all the officers are engineering graduates. The objectives of the study were briefed to the respondents in the departmental meetings and were instructed about the questionnaire. The respondents were then issued with the questionnaire asking them to fill the same based on their experience and value judgement. Random stratified sampling was adopted to ensure adequate representation of both mechanical and electrical officers and engineers covering all the major sections of activities

\section{Nomenclature}

\begin{tabular}{|ll|}
\hline IR & Indian Railways \\
UBLS & Carriage Repair Workshops, Hubli \\
MYSS & Central Workshops, Mysore \\
DSM & Demand Side Management \\
EET & Energy Efficient Technology \\
RET & Renewable Energy Technology \\
FA & Factor Analysis \\
PCA & Principal Component Analysis \\
POH & Periodical Overhauling
\end{tabular}


KMO Kaiser Meyer Olkin

SSE Senior Section Engineers

\subsection{Factor Analysis}

Factor Analysis [FA] is basically a statistical tool for reduction of data (variables) [23]. A variable is anything that changes its value and a factor is a linear combination of variables. Factor is a construct that is not directly observable but that needs to be inferred from the input variables. Factors are statistically independent. FA is a multivariate statistical technique in which there is no distinction between independent and dependent variables. Here, all variables under the study are analyzed together to extract the underlining factors. FA is a useful tool to reduce large number of variables resulting in data complexity to a few manageable factors. These factors explain most part of the variations of the original set of data. FA helps in identifying the underlying structure of the data. As the variables in this study are standardized and highly correlated, FA was justifiably applied to extract the major factors. Significance of correlation matrix is established using Bartlett's test of sphericity. As the number of data points should be four to five times the number of variables in FA, it was ensured that a total of 128 respondents from the two workshops responded to the questionnaire which had 25 variables, thus ensuring the statistical requirement. Kaiser Meyer Olkin (KMO) statistic compares the magnitude of observed correlation coefficients with the magnitude of partial correlation coefficient. A small value of KMO shows that correlation between variables cannot be explained by other variables. The Bartlett's test of sphericity takes the determinant of the correlation matrix into consideration. The test converts it into a Chi-Square statistic with degrees of freedom $=(\mathrm{k}(\mathrm{k}-1)) / 2$, where $\mathrm{k}$ is the number of variables on which FA is applied. Table 1 shows the KMO value for the combined responses at 0.770 (should be $>0.50$ ), and the Bartlett's test for sphericity at 0.000 level (Should be $<0.05$ ) hence meeting the requirements.

Table $1 \mathrm{KMO}$ and Bartlett's Test result

\begin{tabular}{|l|l|l|}
\hline \multicolumn{2}{|l|}{$\begin{array}{l}\text { Kaiser-Meyer-Olkin } \\
\text { Adequacy }\end{array}$} & 0.770 \\
\hline \multirow{2}{*}{$\begin{array}{l}\text { Bartlett's Test of of Sampling } \\
\text { Sphericity }\end{array}$} & Approx. Chi-Square & 1172.873 \\
\cline { 2 - 3 } & df & 325 \\
\cline { 2 - 3 } & Sig. & 0.000 \\
\hline
\end{tabular}

\subsection{Extraction of Factors}

First step undertaken was to decide how many factors are to be extracted from the given set of data. This can be accomplished mainly by three methods viz., Centroid method, PCA method, and maximum likelyhood method. This study has chosen PCA methodology which searches for the weight or factor score coefficient so that the first factor explains the largest population of variance. The first factor is extracted in such a way that it explains the largest portion of variance. This explained variance is subtracted from the original input matrix so as to yield a residual matrix. A second principal factor is extracted from the residual matrix in such a way that the second takes care of most of the residual variance and so on, and this procedure is repeated until there is a very little variance to be explained.

The correlation coefficient between the factor score and variable is called factor loading. Factor loadings are used to compute Eigen values for each factor and the communalities of each variable. For the interpretation of factor, the factor loading matrix is rotated. The main purpose of rotation is to bring the smallest loadings close to zero and its largest loading towards unity. This study has chosen the Varimax method for rotation as this results in independent factor. After completing the rotation, a cut off point for factor loading is selected. There is no hard and fast rule for deciding the cutoff point but generally it is chosen above 0.5 , and the same is adopted in this study as well. Thus, variables with a loading of 0.5 and above are obtained and employed for naming the factor appropriately.

\section{RESULTS AND DISCUSSIONS}

The important objective of the present study was to determine major factors which influence the adoption of ECMs and EETs, and subsequently to prioritize them. The survey adopted 25 variables which are to be grouped appropriately into few manageable factors which can explain major part of the variance. Based on earlier studies undertaken in the field of energy conservation FA (PCA type) has been used. The SPSS output obtained for the two workshops jointly is given in Table 2.

The extracted eight components explained about $65 \%$ of the variability in the original twenty five variables included in the study of UBLS and MYSS, as shown in Table 2. Hence, complexity of the data got reduced considerably by the use of these eight factors with only $35 \%$ loss of information. The table is prepared in the descending order with the topmost variable at the beginning. It can be seen that 22 variables contribute to the 8 factors being extracted. The Scree plot shown in Figure 1 helps in determining the optimal number of components. Generally, the components are extracted on the steep slope. The components on the shallow slope contribute little to the solution. The last big drop occurred between the 8th and 9th components. Hence, the first eight components extracted were retained. Under each of the derived component, all the variables having correlation coefficients greater than 0.5 (as obtained by the rotated component matrix) are considered significant. Keeping these variables in mind the factors are appropriately named in the Table 3. Subsequently, these factors have been ranked based upon the average factor scores. Based on the rankings obtained, it may be observed 
that the employee motivation is the most important factor with a mean factor score of 4.36 .

Table 2 Total Variance explained for combined workshops with 128 respondents

\begin{tabular}{|c|c|c|c|c|c|c|c|c|c|}
\hline \multirow{2}{*}{$\begin{array}{l}\text { Co } \\
\text { m } \\
\text { po } \\
\text { ne } \\
\text { nt }\end{array}$} & \multicolumn{2}{|c|}{$\begin{array}{l}\text { Initial } \\
\text { Value }\end{array}$} & Eigen & \multicolumn{3}{|c|}{$\begin{array}{l}\text { Extracted Sum of } \\
\text { Loadings }\end{array}$} & \multicolumn{3}{|c|}{$\begin{array}{l}\text { Rotation Sums } \\
\text { of Squared } \\
\text { Loadings }\end{array}$} \\
\hline & $\begin{array}{l}\text { Tot } \\
\text { al }\end{array}$ & $\begin{array}{l}\% \\
\text { Var } \\
\text { ian } \\
\text { ce }\end{array}$ & $\begin{array}{l}\mathrm{Cu} \\
\text { mul } \\
\text { ativ } \\
\text { e } \%\end{array}$ & $\begin{array}{l}\text { Tot } \\
\text { al }\end{array}$ & $\begin{array}{l}\% \\
\text { Var } \\
\text { ian } \\
\text { ce }\end{array}$ & $\begin{array}{l}\mathrm{Cu} \\
\text { mul } \\
\text { ativ } \\
\text { e \% }\end{array}$ & $\begin{array}{l}\text { To } \\
\text { tal }\end{array}$ & $\begin{array}{l}\% \\
\mathrm{Va} \\
\text { ria } \\
\text { nce }\end{array}$ & $\begin{array}{l}\mathrm{Cu} \\
\text { mul } \\
\text { ativ } \\
\text { e \% }\end{array}$ \\
\hline 1 & 6.7 & $\begin{array}{l}25 . \\
7\end{array}$ & $\begin{array}{l}25 . \\
7\end{array}$ & 6.7 & $\begin{array}{l}25 . \\
7\end{array}$ & $\begin{array}{l}25 . \\
7\end{array}$ & $\begin{array}{l}3 . \\
8\end{array}$ & $\begin{array}{l}14 . \\
7\end{array}$ & $\begin{array}{l}14 . \\
7\end{array}$ \\
\hline 2 & 1.9 & 7.5 & $\begin{array}{l}33 . \\
2\end{array}$ & 1.9 & 7.5 & $\begin{array}{l}33 . \\
2\end{array}$ & $\begin{array}{l}2 . \\
4\end{array}$ & 9.4 & $\begin{array}{l}24 . \\
1\end{array}$ \\
\hline 3 & 1.8 & 6.9 & $\begin{array}{l}40 . \\
1\end{array}$ & 1.8 & 6.9 & $\begin{array}{l}40 . \\
1\end{array}$ & $\begin{array}{l}2 . \\
3\end{array}$ & 8.8 & $\begin{array}{l}32 . \\
9\end{array}$ \\
\hline 4 & 1.5 & 5.7 & $\begin{array}{l}45 . \\
8\end{array}$ & 1.5 & 5.7 & $\begin{array}{l}45 . \\
8\end{array}$ & $\begin{array}{l}1 . \\
9\end{array}$ & 7.5 & $\begin{array}{l}40 . \\
4\end{array}$ \\
\hline 5 & 1.4 & 5.4 & $\begin{array}{l}51 . \\
2\end{array}$ & 1.4 & 5.4 & $\begin{array}{l}51 . \\
2\end{array}$ & $\begin{array}{l}1 . \\
9\end{array}$ & 7.2 & $\begin{array}{l}47 . \\
6\end{array}$ \\
\hline 6 & 1.3 & 4.8 & $\begin{array}{l}56 . \\
0\end{array}$ & 1.3 & 4.8 & $\begin{array}{l}56 . \\
0\end{array}$ & $\begin{array}{l}1 . \\
6\end{array}$ & 6.2 & $\begin{array}{l}53 . \\
7\end{array}$ \\
\hline 7 & 1.1 & 4.4 & $\begin{array}{l}60 . \\
4\end{array}$ & 1.1 & 4.4 & $\begin{array}{l}60 . \\
4\end{array}$ & $\begin{array}{l}1 . \\
6\end{array}$ & 6.1 & $\begin{array}{l}59 . \\
8\end{array}$ \\
\hline 8 & 1.1 & 4.3 & $\begin{array}{l}64 . \\
7\end{array}$ & 1.1 & 4.3 & $\begin{array}{l}64 . \\
7\end{array}$ & $\begin{array}{l}1 . \\
3\end{array}$ & 4.8 & $\begin{array}{l}64 . \\
7\end{array}$ \\
\hline
\end{tabular}

Table 3 below gives the values of correlation, mean variable score, average factor score (which is the average score of all the variables included in the factor) and lastly the factor names. The factors have been arranged as per their average score and ranked accordingly. It is clearly evident that motivation to employees is the need of the hour, as it has the highest mean variable score and also highest correlation. Due to advancement in technologies in the dynamically changing world, knowledge about the new technologies being introduced is also of prime importance. The various measures that can be adopted to ensure better efforts towards ECMs and EETs should be known to all the concerned stake holders. The factor analysis of 25 variables in two workshops of Indian Railways arrived at eight factors with the top ranker being the need for "Motivation for staff". It is clearly evident that workshops' being in the government sector salary is not the only motivator and as such other modes of motivation can be thought off to increase the adoption of energy conservation measures (ECMs) and energy efficient technologies (EETs) in these units. Secondly, it was found that attitude and knowledge of staff can be suitably improved to derive greater benefits in the long run. Indian Railways is passing through a difficult phase in terms of financial aspects due to increased staff costs which are not commensurate with the revenues and as such development projects have been hit. Hence, the focus of railways to reduce its costs in terms of fuel of railway budget needs greater push by adopting measures to motivate the staff towards the same. Installation of preventive measures by means of having equipment health records, having adequate inventory of consumable and non consumable spares for the machinery and equipment, having meetings for EC activities, conducting preventive maintenance of equipment, periodical training to staff can contribute towards better utilization of the valuable assets which generally are EET and thus lead to EC. In government organizations' decisions are made cautiously considering future repercussions and are hence generally delayed. This leads to loss of morale and at times sends wrong signals to the staff. A consecrated effort in the way of installing and maintain EET can be undertaken to drive the message loud and clear among one and all in the organisation. Management has an important role in giving the required output from the shops in the desired quality standards. The onus of procurement, installation, commissioning and maintenance of EET is an added effort which the management has to put in addition to the specified duties. The procurement process is another factor which emerges out of the study of these variables. As a onetime exception concessions can be made to ensure easy procurement of better technologies by way of price preferences so that the reliable technologies are adopted which boost the confidence of the organisation. Human factor is crucial to ensure the proper operation, maintenance of the EET installed and they by contribute towards the drive for EC. Once the drive is begun as the days pass by it shall get reinforced and gain momentum which shall be of good not only to the workshops in particular but to the organisation at large. The transfer policy can be streamlined and be organised which can encourage the staff, supervising engineers and officers alike to ensure their role and contributions in the field of selecting, procuring, installing and maintaining the EET.

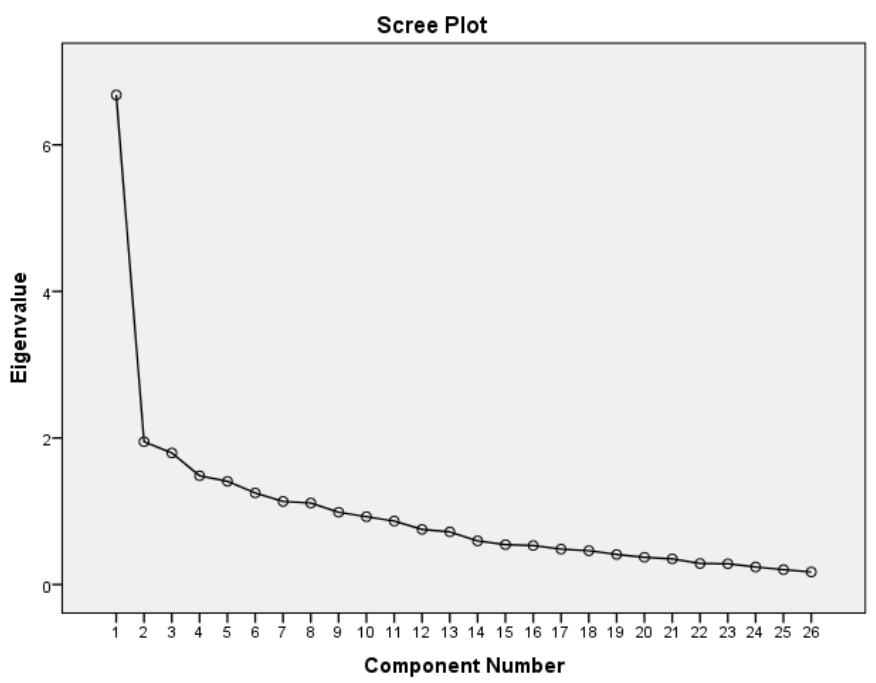

Fig -1: Scree Plot of 128 respondents 
Table 3 Correlation, Factor Names and Rankings

\begin{tabular}{|c|c|c|c|c|c|}
\hline $\begin{array}{l}\mathrm{R} \\
\mathrm{a} \\
\mathrm{n} \\
\mathrm{k}\end{array}$ & Variables & $\begin{array}{l}\text { Co- } \\
\text { Relati } \\
\text { on }\end{array}$ & $\begin{array}{l}\text { Mean } \\
\text { Varia } \\
\text { ble } \\
\text { Score }\end{array}$ & $\begin{array}{l}\text { Aver } \\
\text { age } \\
\text { Facto } \\
\text { r } \\
\text { Score }\end{array}$ & $\begin{array}{l}\text { Factor } \\
\text { Name }\end{array}$ \\
\hline 1 & Motivation & 0.8 & 4.36 & 4.36 & $\begin{array}{l}\text { Motiva } \\
\text { tion }\end{array}$ \\
\hline \multirow{3}{*}{2} & Attitude & 0.75 & 4.32 & \multirow{3}{*}{4.27} & \multirow{3}{*}{$\begin{array}{l}\text { Knowl } \\
\text { edge \& } \\
\text { attitud } \\
\text { e }\end{array}$} \\
\hline & $\begin{array}{l}\text { Optimum } \\
\text { Utilisation }\end{array}$ & 0.64 & 4.3 & & \\
\hline & EC Capability & 0.55 & 4.39 & & \\
\hline \multirow{7}{*}{3} & Inventory Mgt & 0.74 & 4.18 & \multirow{7}{*}{4.27} & \multirow{7}{*}{$\begin{array}{l}\text { Preven } \\
\text { tive } \\
\text { Measu } \\
\text { res }\end{array}$} \\
\hline & Monitoring Health & 0.72 & 4.19 & & \\
\hline & Regular Mtgs & 0.72 & 4.05 & & \\
\hline & $\begin{array}{l}\text { Increasing } \\
\text { Awareness }\end{array}$ & 0.67 & 4.37 & & \\
\hline & $\begin{array}{l}\text { Preventive } \\
\text { Maintenance }\end{array}$ & 0.61 & 4.35 & & \\
\hline & Periodical Trg & 0.58 & 4.41 & & \\
\hline & $\begin{array}{l}\text { Technology of } \\
\text { Machines }\end{array}$ & 0.53 & 4.32 & & \\
\hline \multirow{2}{*}{4} & Prompt Decisions & 0.73 & 4.23 & \multirow[b]{2}{*}{3.88} & \multirow{2}{*}{$\begin{array}{l}\text { Timely } \\
\text { Decisi } \\
\text { on } \\
\text { Makin } \\
\mathrm{g}\end{array}$} \\
\hline & Finance Dept & 0.60 & 3.54 & & \\
\hline \multirow[t]{2}{*}{5} & $\begin{array}{ll}\text { Awards } & \text { for } \\
\text { Motivation } & \end{array}$ & 0.73 & 4.06 & \multirow[t]{2}{*}{3.86} & \multirow{2}{*}{$\begin{array}{l}\text { Motiva } \\
\text { tion } \\
\text { for EC }\end{array}$} \\
\hline & Focus on quality & 0.70 & 3.66 & & \\
\hline \multirow{3}{*}{6} & Machine Handling & 0.68 & 4.09 & \multirow{3}{*}{3.85} & \multirow{3}{*}{$\begin{array}{l}\text { Manag } \\
\text { ement } \\
\text { role }\end{array}$} \\
\hline & $\begin{array}{l}\text { Procurement } \\
\text { process }\end{array}$ & 0.66 & 3.79 & & \\
\hline & $\begin{array}{l}\text { Centralised } \\
\text { Decision Making }\end{array}$ & 0.56 & 3.68 & & \\
\hline \multirow[t]{2}{*}{7} & $\begin{array}{l}\text { Least Cost } \\
\text { Procurement } \\
\text { Policy }\end{array}$ & 0.73 & 3.78 & \multirow[b]{2}{*}{3.51} & \multirow{2}{*}{$\begin{array}{l}\text { Procur } \\
\text { ement } \\
\text { policy }\end{array}$} \\
\hline & $\begin{array}{ll}\text { Ego/Feeling of } \\
\text { Insignificance }\end{array}$ & 0.61 & 3.25 & & \\
\hline \multirow[t]{2}{*}{8} & $\begin{array}{l}\text { Role of Trade } \\
\text { Unions }\end{array}$ & 0.85 & 2.9 & \multirow[t]{2}{*}{3.06} & \multirow{2}{*}{$\begin{array}{l}\text { Human } \\
\text { factor }\end{array}$} \\
\hline & Transfer Policy & 0.53 & 3.22 & & \\
\hline
\end{tabular}

\section{CONCLUSIONS}

IR is in the forefront of installing EET and has massive EC measures being undertaken in all its units be it production units, workshops and divisions. This is clearly evident from the state of art equipments in its establishments which are procured against global tenders by Central Organisation for Modernisation of Workshops. Most of the earlier era equipments have been made redundant and new energy efficient equipment have been installed like Inverter based welding plants, Airless Spray Painting equipment; VFD based Machine tools, Traverser and EOT Cranes. The study reveals that out of the 25 variables motivation to employees is the greatest factor which can contribute towards implementation of EC measures and successfully sustaining them over a period of time. Railways do have a structured motivation programme right from the Ministry of Railways level to down the individual divisions and workshops level. A separate set of awards can be constituted to encourage healthy competition amongst various shops of the workshops. This will lead to benchmarking and regular monitoring and thus the EET can be successfully implemented and sustained. Secondly the knowledge about EC, the various measures undertaken at all levels needs to be dissseminated by means of posters, seminars, workshops at regular intervals. Training is provided for the operating and maintenance staff as and when new equipment is procured. This information needs to be widely circulated among all the colleague supervisors and technicians so that the optimum utilisation of the equipment can be undertaken and underutilisation or overloading is avoided.

This study was undertaken in two carriage repair workshops located in south India and thus the study can be further extended to other geographical parts of the nation. The study finds out that the average experience of its engineers and officers is considerably high and as such their value judgement needs to be given due consideration while formulating policies. The study also reveals that the attrititon rates in IR is almost negligible considered to other transport sectors or industry for that matter and hence keeping the associates motivated can yield improved results.

\section{ACKNOWLEDGEMENTS}

The authors would like to thank Chief Workshop Managers of both the workshops for encouraging the research and also actively participating in the study. We thank all other officers and engineers of Carriage Repair workshop, Hubli and Central Workshop, Mysore for sparing their valuable time in understanding the questionnaire and filling the same based on their experience and value judgment.

\section{REFERENCES}

[1]. http://www.worldenergyoutlook.org/ IEA Energy Technology Perspectives 2010 - Scenarios \& Strategies to 2050, ISBN 978-92-64-08597-8 (2010)( IEA (International Energy Agency, 2013 World Energy outlook)

[2]. www.cea.nic.in/reports/yearly/lgbr_reports.pdf last accessed on 23.10.13 ( CEA Website)

[3]. Indian Railways Magazine Annual Issue April 2012 pp. 38-40.

[4]. Indian Railways Magazine May 2012 issue pp.27 
[5]. Indian Railways Budget Speech delivered by Hon'ble Minister of Railways, Feb 2013 available at www.indianrail.gov.in/English_Speech_2013-14.pdf, pp 15

[6]. BEE Awards 2012 available at www.bee-india.nic.in

[7]. Electrical PCDO of Carriage Repair Workshop for 2011

[8]. Standard Note of Carriage Repair Workshop, Hubli from 2010 to 2012

[9]. Standard Note of Central Workshops, Mysore from 2010 to 2012

[10]. Somashekar S, N. Nagesha 2010. An empirical study of factors influencing urban household energy consumption in India, The Ecoscan 4(4): 339-342, 2010

[11]. Nagesha N. and Balachandra P., (2006). "Barriers to Energy Efficiency in SSI Clusters: Multicriteria based prioritisation using Aalytical Hierarchy Process", Energy, Vol 31, No 12, pp.1633-1647

[12]. Andreas Hoffrichter, Arnold R. Miller, Stuart Hillmansen, Clive Roberts, 2012. Well to Wheel analysis for electric, diesel and hydrogen traction for railways, Transportation research Part D 17 (2012) 28-34

[13]. EIA (Energy Information Administration) (2011), "International Energy Outlook 2011" Website: http://www.eia.doe.gov/oiaf/ieo/world.html.

[14]. Abdelaziz E.A., R. Saidur, S. Mekhilef, 2011. A review on energy saving strategies in industrial sector, Renewable and Sustainable energy reviws, 15 (2011) 150-168

[15]. Jenny Palm, Patrik Thollander, 2010. An interdisciplinary perspective on industry energy efficiency, Applied Energy 87 (2010) 3255-3261

[16]. Weber, L. 1997. Some Reflections on Barriers to the Efficient Use of Energy, Energy Policy, Vol. 25, No. 10, pp. 833- 835.

[17]. Baranzini, A. and Giovannini, B. (1996), "Institutional and Cultural Aspects of Energy Consumption Modelling", Structural Transformation Process towards Sustainable Development in India and Switzerland, INFRAS publication, Zurich, Switzerland

[18]. JIA Shunping, PENG Hongquin, LIU Shuang, ZHANG Xiaojie, 2009. Review of Transportation and Energy Consumption Related Research, J journal of Transportation Systems Engineering \& Information Technology, 2009, 9(3), 6-16

[19]. Suresh D. Mane and D.Ghosh Roy "Carriage Repair Workshop - Hubli 1885- 2008, Indian Railways magazine July 2008 pp 18-19.

[20]. Electricity Bill of Railway Workshops issued by Hubli Electricity Supply

[21]. Electricity Bill of Mysore Workshops issued by Chamundeshwari Electricity Supply Corporation, Mysore from Jan 2007 till Dec 2011.

[22]. Energy audit report of South Central Railway Tirupati Workshop, Andhra Pradesh.

[23]. Julie Pallant, (2007), SPSS - Survival Manual- a Step by step guide to data analysis using SPSS for Windows, McGraw Hill, England 